\title{
Historical Analysis of Green Development Concept in China
}

\author{
Tian Liu ${ }^{a}$, Hongbin Wang ${ }^{b}$ and Chunyuan Liu \\ School of Harbin University of Commerce, Harbin 150028, China \\ a40459422@qq.com, b18846040726@163.com
}

Keywords: Ecological civilization, beautiful China, green development concept.

\begin{abstract}
In ancient China, which was a feudal society and an agricultural civilization for a long time, there existed the idea of "harmony between man and nature", which advocated the harmonious coexistence of man and nature. After the founding of the people's Republic of China, China also experienced extensive development, which led to serious environmental pollution. The concept of green development was gradually developed from one view to the main idea of guiding the country's economy, society and development. The green development concept to guide the construction of ecological civilization and the beautiful China, achieve sustainable development, rise as the guiding ideology of the construction of the Party leadership of the country, leading Chinese people go on the road of socialism on Chinese.
\end{abstract}

\section{The idea of green development in Chinese traditional culture}

Although the concept of green development is the development process of modern industrial society, but the Chinese civilization has a long history, has experienced the development and change of five thousand years of history, has produced many about the development of thoughts and ideas, especially in the contention of a hundred schools of thought in the spring and Autumn Period, already contains rich ecological ethics, green development thoughts for human beings civilization left a large number of theoretical wealth. China's long feudal society is a typical agricultural civilization, and a simple and conservative agricultural civilization has a natural affinity for nature. It is the traditional cultural basis for the formation of green development thought in china.

"The relationship between heaven and man" is the overarching problem of Chinese ancient agricultural civilization system, great ancient historian Sima Qian wrote in "historical records", "the combination of heaven with man, through the change of ancient and modern, a home of kyrgyzstan." With "benevolence" as the core of the Confucian has become the mainstream of Chinese culture, with its advocacy of "love" and "compassion" ethics, "benevolence" is mapped to the development and utilization of natural development including the response to the idea of not unrelated. The "Inaction", "one" as the core of Taoism is advocated to follow the laws of nature and development concept, Lao Tzu, master of philosophy of Taoism, the originator of ancient dialectics, for the relationship between man and nature "based", "return to nature" thought, development of the concept of advocating "imitation of nature" "Wuwei Shun", will be regarded as a part of the nature, rather than the natural world leader, that person should not violate the "Tao" of the objective laws of the "natural" natural attributes, but should follow the law of "all things in life the development of" Tao ", and not do and the development and utilization of all things, all things should conform to the law of development. As an important theoretical source of the Taoist thinkers Chuang-tzu put forward "Qiwulun", that all nature, including human beings are uniform in nature, as a part of the nature of human beings should respect and comply with nature, realize the "world and I, for one, the highest level of development and I did all things".

In the cultural field, longing for the pastoral life of the poetry and prose is to be too numerous to enumerate. The Han Dynasty Zhang Heng's "Gui", on behalf of the Jin Dynasty period famous pastoral poet Tao Yuanming's "Peach Blossom Spring", the poet Xie Lingyun, Xie Tiao created a lot of landscape poems. Since then, landscape and pastoral have become the carriers of poetry to express the harmony between man and nature. To the Tang Dynasty, landscape and pastoral poetry entered a period of prosperity, and formed a "Pastoral Poetry", the emergence of a large number of writing 
pastoral poems mainly poets, green culture has become an important Chinese gene of traditional culture.

Therefore, China traditional culture throughout the "harmony between man and nature" of the overall thinking, will be included in the human survival of the natural world, as the "heaven" as an indivisible whole, interdependent, prosperity and symbiosis, the highest realm of the formation of the relationship between man and nature of the ultimate datong. Today, although the human productivity achieved a qualitative progress, but in the process of transforming the nature is found, the economic development and ecological harmony is still the objective truth, the concept of common development is the same, is not able to change the progress of mankind, therefore, the traditional culture of "man and nature" coordinated the whole idea is still able to provide intelligence support for the modern concept of development, can promote the transformation of human production mode, providing ideological support for green development.

\section{The development course of green development thought since the founding of the people's Republic of China}

After the founding of new China, the first task of the Communist Party of China to lead the people in building a new China is to develop. After more than 100 years of humiliating history of semi colonial and semi feudal society, the former powerful Chinese Empire appeared fragile in the face of the impact of western industrial civilization. China Communist Party led the people to overthrow the three big mountains of oppression, realizing national independence. Therefore, the new China's first priority is to achieve rapid development, raise the level of productivity, change the mode of production to adapt to the world trend of industrial civilization.

(1) The rapid development model for restoring social production at the early stage of the founding of the people's Republic of China

In the early days of new Chinese, learning the Soviet model, build a huge industrial system, the unidirectional productivity is interpreted as conquest, development and utilization of natural ability for industrial services, in a few years, creating a history of human civilization and industrialization miracle. In his theory of practice, Mao Zedong pointed out, "human cognition relies mainly on the productive activities of matter, and gradually understands the phenomena of nature, the nature of nature, the laws of nature, and the relationship between man and nature."." In 1959 the "economic construction is scientific, honest to study" the article is to remind people if there is no understanding of nature, or unclear, will touch the nail, naturally will punish us, will resist." The modern industrial system has laid a solid foundation for the development of Chinese, China people's exploitation of nature, transform nature is the degree of the long agricultural society incomparable, Chinese by Marx's Communist Party guiding practice, adhere to the scientific development in the process of transforming nature, socialist construction, that follow the law of nature. At this stage, the restoration of social production, although accompanied by a lot of environmental damage, violated the laws of nature, but did not produce serious consequences of ecological damage.

(2) Extensive and rapid development pattern since the reform and opening up

Since the reform and opening to the outside world, the national construction has taken economic construction as the center of gravity after experiencing twists and turns, and large-scale modernization construction has been spread out on the whole of China again. As the Communist Party of China has re examined the situation in the world, peace and development are the main tasks of the world today. China is opening to the outside world and integrating with the world. In the opening speech of the Twelfth National Congress of the Communist Party of China (CPC), Deng Xiaoping pointed out: "China's modernization drive must proceed from China's reality. Whether it is revolution or construction, we should pay attention to study and learn from foreign experience. However, copying other countries' experience and other countries' models will never succeed. We have had many lessons in this respect."

With the deepening of reform and opening, the cadres and the masses to protect the environment awareness is not enough, in the process of economic development imperceptibly re take the old path 
after the first pollution, the environmental problems caused the large-scale economic construction has become increasingly prominent, the Communist Party Chinese actively, deepen understanding. Conform to the changing mode of development in the world, realize the trend of green development, and actively explore the road of sustainable development. In order to get out of a China characteristic socialism development road, to avoid repeating the ecological crisis of Western civilization appeared in the process of development, the Communist Party attaches great importance to the development of China, promote green development, the importance of environmental protection. In 2001, when Jiang Zemin inspected the work in Hainan, he said, "we should strengthen the environmental awareness and ecological consciousness of the cadres and the masses.". To make the cadres and the masses truly clear in mind, to destroy the resources and the environment is to destroy the productive forces, to protect the resources and the environment, to protect the productive forces, to improve the resources and the environment, and to develop the productive forces."

The Chinese government passed the first law on environmental protection in 1979, "the law of the People's Republic of China on environmental protection" (Trial Implementation). To raise environmental protection in the form of law as the will of the state, to restrict and regulate economic behavior, and to contribute to the legal consciousness of the construction of ecological civilization in the whole society. In the early twenty-first Century, China promoted ecological civilization as an important goal of a well-off society, and put green development in the party's guiding ideology.

(3) Building ecological civilization and realizing sustainable development

The report clearly put forward the development goal of the construction of ecological civilization, the material civilization and spiritual civilization, political civilization, ecological civilization is put forward, the goal of building a well-off society is more and more clear, more and more rich connotation. The construction of ecological civilization has basically formed the industrial structure, growth mode and consumption pattern to conserve energy resources and protect the ecological environment. A larger scale of the circular economy, the proportion of renewable energy increased significantly. The discharge of major pollutants has been effectively controlled and the quality of the ecological environment has been improved markedly. The concept of ecological civilization is firmly established in the whole society." The party in the fourth Plenary Session of the 17th CPC Central Committee to enhance the construction of ecological civilization to a strategic height along with economic construction, political construction, cultural construction and social construction, that is to say the construction of ecological civilization is an important part of "five in one" construction target, has become an important goal of sustainable development will not be less.

(4) The "five in one" and "green" development philosophy

Since the $18^{\text {th }}$ National Congress of the Communist Party China, the transformation of structural adjustment become the priority among priorities of the economic and social development, people's awareness of the environment has become increasingly high, the ecological and environmental factors in the process of economic development also reached the height of hitherto unknown attention. The eighteen Party Congress report pointed out that the construction of China socialism, general layout is economic construction, political construction, cultural construction, social construction, ecological civilization construction". The fifth Plenary Session of the 18th CPC Central Committee the party put forward the innovation development and coordinated development, green development, open development, sharing development five development ideas, not only enrich and develop the theory of socialist system Chinese, also for the new normal in-depth to promote the construction of ecological civilization provides theoretical guidance and practical guide.

With Xi Jinping as the general secretary of the CPC Central Committee is to improve the ruling, green development and its important level, in the eighteen session of the Standing Committee of the Political Bureau meeting, general secretary Xi Jinping put forward the set people thinking concern "if still extensive development, even to achieve a GDP goal of doubling the pollution will be what kind of situation? By then, the resources and environment may not bear the full load. The economy has gone up, the happiness of the people has been greatly reduced, and even a strong discontent has come up. What is the situation? Therefore, we can not only strengthen the ecological civilization construction, strengthen the ecological environment protection, advocate green low-carbon lifestyle, 
just as an economic problem. There's a lot of politics in it." In July 18, 2013, the International Forum on ecological civilization held in Guiyang, Xi Jinping said in the letter: "towards a new era of ecological civilization, build a beautiful China, is an important part of China dream of the great rejuvenation of the Chinese nation." China will take the road of green development and build a beautiful China with ecological civilization, which is regarded as the only way to realize national rejuvenation. In September 7, 2013, the general secretary Xi Jinping during a visit to Kazakhstan at the Nazarbayev University speech, and students in the interactive process, referring to the relationship between economic development and environmental protection, he put forward the famous "two mountains" discussion, he pointed out: "we should not only beautiful scenery, also jinshanyinshan. Nanjing to beautiful scenery, beautiful scenery and is not gold and silver, gold and silver". Not only to protect the ecological environment, to keep the green mountains and rivers in the process of development, but also the development of green economy, green development path, to the beautiful scenery to develop.

\section{Building a beautiful China and achieving green development}

The revised version of the People's Republic of China environmental protection act, which is known as "the strictest in history", was voted on at the eighth session of the Standing Committee of the twelve National People's Congress on April 24, 2014. The law was formally implemented in January 1, 2015. In May 5, 2015, the CPC Central Committee and State Council issued "on accelerating the construction of ecological civilization", the 9 part contains a total of 35 rules of the "opinions", throughout all through the "respect for nature, comply with nature and protect nature", "the idea of green development is the beautiful scenery of Jin Shanyin mountain, the development of philosophy to establish the harmony between man and the the natural development of economic and social development activities must conform to the laws of nature.

Throughout the history of the development Chinese long, the relationship between man and nature is always an important contradiction of social development is not open around. To firmly establish the concept of green development, green development to explore the concept of ecological civilization construction in the new path, is the inevitable trend of historical development. Vigorously promote the process of the construction of the beautiful Chinese, realize the sustainable development, is the inevitable requirement of road Chinese characteristics socialism. To form the green development concept of green development and way of life as the goal, is the party's proposed eighteen since the new development guide, will promote the concept of social development has a profound revolution.

\section{References}

[1] Mao Zedong anthology volume first, people's publishing house, 1991, 282-283.

[2] Mao Zedong anthology volume eighth, people's publishing house, 1991, 72

[3] Deng Xiaoping anthology volume third, people's publishing house, 2001, 2-3.

[4] Jiang Zemin speech inspection in Hainan (February 27, 2001),Jiang Zemin on the socialist Chinese (selected) 282

[5] The great banner of socialism with China Hu Jintao , and strive for new victories in building a moderately prosperous society (October 15, 2007), file at the Seventeenth National Congress of the Communist Party of Chinese Assembly 18-20

[6] The Publicity Department of the CPC Central Committee General Secretary Xi Jinping important speech reading series, Beijing: learning press, 2014, 120 